\title{
On the Effect of Negotiated Metacognitive Assessments on Improving Listening Comprehension: A Case of Iranian EFL Learners
}

\author{
Masoud Yazdani Moghadam \\ Islamic Azad University, Garmsar, Iran \\ E-mail: Yazdanimoghaddam@yahoo.com \\ Neda Sadat Sajadi Rad (Corresponding author) \\ Islamic Azad University, Garmsar, Iran \\ E-mail: nedasajadi2014@yahoo.com
}

Received: 20-10- 2014

Accepted: 10-01- 2015

Advance Access Published: January 2015

Published: 01-05-2015

doi:10.7575/aiac.ijalel.v.4n.3p.212 URL: http://dx.doi.org/10.7575/aiac.ijalel.v.4n.3p.212

\begin{abstract}
This paper reports a study investigating the role of negotiated assessment of metacognitive listening strategies in enhancing listening comprehension. To this aim, 60 Iranian EFL learners at intermediate level of language proficiency were assigned to an experimental $(\mathrm{n}=30)$ and control group $(\mathrm{n}=30)$. An attempt was made by the teacher in experimental group to raise students' awareness of metacognitive strategies both prior to and after the doing listening comprehension tasks in a time bracket of eight weeks. Nonetheless, the control group followed conventional productoriented approach to listening instruction; that is, no attempt was made to engage them in metacognitive instruction. Listening comprehension of both groups was assessed by listening section of IELTS at the onset and end of the study. Results of the study revealed that negotiated metacognitive assessment managed to significantly increase gains in listening comprehension. Furthermore, the experimental group significantly outperformed the control group. The results gave more credence to the positive role of process-based approach to teaching listening comprehension. The results are discussed in the light of metacognition and some pedagogical implications are included.
\end{abstract}

Keywords: Listening comprehension, metacognition, metacognitive awareness, negotiated metacognitive assessment

\section{Introduction}

Listening comprehension is often considered as the 'Cinderella skill' of second language acquisition research (Vandergrift, 1997). Echoing the same view, Albeeva and Stranks (2013) reiterated that this skill has been less explored in spite of its critical importance to second language learning. As pointed out by Buck (2003), due to the inadequacy of research on listening comprehension, "we still do not fully understand what the important sub-skills of listening are; nor are we sure what information educators need to teach listening better" (as cited in Albeeva \& Stranks, 2013, p. 198). However, in the face of such lengthy exile and absence from language teaching programs, fortunately, listening comprehension has obtained a better position nowadays and some weight has been attached to it. Goh (2008) maintained that EFL teaching programs have recently placed some premium on instructing listening strategies and metacognition in order to enrich and enhance teaching listening comprehension.

Now, additionally, there is some convincing evidence in the SLA research underscoring the role of metacognitive awareness of listening strategies in successful listening comprehension. Goh and Taib (2006), for instance, pointed out that increasing learners' awareness of listening strategies can make a contribution to developing listening by lessening their level of anxiety and increasing their confidence. In the same line of inquiry, some studies (e.g., Goh, 1997, 2000, 2002; Vandergrift, 2002, 2003, 2006) have provided compelling evidence in favor of the close relationship between metacognitive awareness of listening strategies and listening comprehension. They indicated that learners possessing higher awareness of metacognitive listening strategies can draw upon a richer repertoire of strategies to deepen and broaden their listening comprehension; further, they can implement a wider range of strategies to resolve their listening comprehension problems.

Furthermore, in a likewise manner, some studies in Iranian context have substantiated a positive relationship between awareness of metacognitive listening strategies and listening comprehension (e.g., Baleghizadeh \& Rahimi, 2011; Tavakoli, Hashemi, \& Rezazade, 2012). Thus, the SLA research attention should be directed to devising effective approaches for increasing learners' awareness of listening strategies. Goh and Taib (2006) pointed out that we require teaching methods "which include reflection and discussion, teacher modeling, integrated sequences of activities that focus alternately on text and process, as well as perception practice that facilitates recognition of segments of speech" (p. 231). To answer the call for such a method, this study set out to examine the effect of interactive teacher-student assessment of metacognitive listening strategies on developing listening comprehension of Iranian EFL learners. 


\section{Review of the Literature}

\subsection{Theoretical background to the study}

\subsubsection{Metacognition}

Metacognition has been defined and conceptualized variedly by different scholars; nonetheless, it is commonly referred to as thinking about thinking or cognitive processes in order to better orchestrate and regulate its undertaking. One of the most often-quoted definitions is from Flavell (1976):

\section{'Metacognition' refers to one's knowledge concerning one's own cognitive processes and products or anything related to them ... Metacognition refers, among other things, to active monitoring and consequent regulation and orchestration of these processes in relation to the cognitive objects or data on which they bear, usually in the service of some concrete goal or objective. (p. 232)}

Further, Flavell drew a distinction between metacognitive experience and metacognitive knowledge. To him, the former encompasses transitory feelings about our thinking processes which do not bring about any noticeable knowledge about learning while the latter entails three types of knowledge: person, task, and strategy. Person knowledge captures "knowledge about ourselves as learners, and includes our perceptions of our abilities and factors that affect the success or failure in our learning (for example age, aptitude, personality, gender, and learning style)" (Goh, 2010, p. 182). Task knowledge deals with the knowledge about the characteristics and objectives of the task and the demands it is imposing on learners. Further, it involves knowledge of required procedures to perform a task successfully. The third part of metacognitive knowledge, strategy knowledge, encapsulates the knowledge about effective strategies that can guide and help learners to meet task objectives. Further, strategy knowledge deals with knowing about the ineffective strategies which are currently used but must be reconsidered or discarded.

Listening is conceived of as a stressful and demanding task for beginning and intermediate language learners, who are often unable to process information quickly enough to make sense of what is said (Goh \& Taib, 2006; Graham, 2006). This problem might stem from cognitive, metacognitive or/and affective factors. Thus, it is incumbent upon teachers to aid and assist learners to develop listening skill since the invisibility of its underpinning processes makes it too painstaking and complex to be learned by learners on their own. Goh and Taib proposed that active participation of learners in teaching and assessing listening can ease the burden of developing listening comprehension since receptive skills are naturally accompanied with tedium and frustration. Additionally, active involvement of learners in instructing listening processes can prompt them to gain further control over their learning. They stressed that making learners aware of the underlying skills and strategies, what referred to as metacognitive awareness of listening comprehension, is of paramount importance for honing listening comprehension. Goh and Taib went on to add that "asking learners to report and discuss the thought processes that they engage in during listening tasks" (p. 230) can be conducive to raising metacognitive awareness of listening. As a result, the development of "metacognitive knowledge will enable learners to appraise themselves and to select appropriate strategies for improving their performance" (Goh \& Taib, 2006, p. 223). Goh (2008) speculated that metacognitive awareness can enhance listening comprehension by changing the ways second language learners approach and deal with listening tasks; more precisely, learners with higher degrees of metacognitive awareness can plan how to listen, predict and prepare themselves for coping with task demands, can monitor their listening comprehension process and evaluate all processes they have gone through to do the task. In view of the aforementioned discussion, it can be postulated that developing metacognitive awareness is at the center of language teaching approaches intending to develop autonomous language learners. By the same token, Goh (2010) stressed that "metacognitive knowledge can lead an individual to select, evaluate, revise, or even abandon tasks, goals, and strategies; in other words, to self-regulate their learning and thinking" (p. 182).

\subsection{Empirical studies on metacognitive awareness of listening}

Investigating instructing listening comprehension within the framework of metacognitive awareness is a very young field of study. Goh and Taib (2006) carried out a small-scale study with ten primary school students. The instruction program pursued three stages: listen and answer, reflect-report, and discuss. In the first phase of the study, the learners listened to some test-like tasks and answered given comprehension questions. In fact, this step was undertaken without any intervention on the part of teacher. For the second step, the learners reflected on their task performance in retrospect; this phase was performed individually and was guided by four questions written on the board. This stage was aimed at prompting the learners to verbalize and report the processes they undertook during task performance. In the third stage of instructional program, each learner read his/her reflective notes aloud and the teacher and other students commented on it. Results of the study unfolded that the learners' metacognitive knowledge and confidence increased noticeably. Further, a considerable increase in listening comprehension was reported; this process-based approach to teaching listening was proved to be highly beneficial for weaker listeners.

Cross (2009) conducted a study including 20 Japanese EFL learners. The study pursued a 'pedagogical cycle' proposed by Vangergrift (2004); it entailed prediction, monitoring, problem identification and evaluation. Comparing the results of a pre-test and post-test indicated that the treatment successfully managed to increase the listening comprehension of three of the four less-skilled listeners to a notable extent while it was beneficial to one of the four skillful listeners. Cross argued the results were justifiable on the grounds that the pedagogical cycle assisted the less-skilled learners to learn how to 'orchestrate' the required cognitive and metacognitive strategies. Nonetheless, the more-skilled listeners 
have reached a ceiling or threshold level of comprehension and orchestration of the requisite strategies and processes so the instruction failed to aid them significantly.

Moreover, Vandergrift and Tafaghodtari (2010) examined the effect of a process-based approach to teaching listening comprehension. They incorporated metacognition into instruction program by pursuing the following stages: prediction/planning, monitoring, evaluating ad problem solving. The experimental group received instruction according to the aforementioned steps while the control group did not receive any special instruction on listening processes; in fact, the control group only listened to some texts as many as the experimental group did. Results of the study demonstrated that the metacognitive awareness of the experimental group was enhanced more than that of the control group. Additionally, it was evidenced that the experimental group outstripped the control group in terms of gains in listening comprehension.

It is worthy to add that some studies have investigated the role of metacognitive instruction in Iranian context. For example, Rahimi and Katal (2013) compared the effect of metacognitive approach to listening with traditional productoriented approached. The metacognitive group received metacognitive instruction on the basis of the pedagogic cycle while the product-based group was not involved in any instruction on metacognitive strategies. Results of the study evidenced that there was a significant difference in metacognitive awareness of both groups after 16 sessions of treatment while the gains in listening comprehension were not significantly different.

More recently, Fahim and Fakhri Alamdari (2014) delved into the effect of two models of metacognitive instruction on developing listening comprehension over a time bracket of ten weeks. Their study included three groups of Iranian EFL learners at the intermediate level of language proficiency. The first experimental group was involved in a linear cycle of metacognitive instruction; that is, this group was instructed on one of the metacognitive strategies per session. The second experimental group went through a cyclic pedagogical cycle named Metacognitive Pedagogical Sequence (Vandergrift \& Goh, 2012) and learners were afforded opportunities to dialogue about the required skills and strategies for successful task performance. The third group, control group, worked on the same tasks as the experimental groups did, but was exposed to no specific instruction on metacognition. Results of the study unveiled that both experimental groups outperformed the control group; further, it was substantiated that the second experimental group which was instructed how to orchestrate the metacognitive strategies together and benefited from collaborative dialogue outstripped the first experimental group.

\subsection{Purpose of the study and research questions}

As described in the previous section, SLA research has provided evidence supporting the role of metacognitive awareness in listening comprehension, but in spite of this agreed-upon point, there is a debate over the optimal way to teach metacognitive awareness of listening. Thus, this study intended to throw some light on the effect of interactive method of metacognitive assessment on cultivating listening comprehension of Iranian EFL learners. This strategy was undertaken on the premise that one of the cornerstones of metacognitive instruction is laying an appropriate groundwork for social and collaborative interactions to foster learning processes (Goh, 2010).

Precisely put, the current study is driven by the following questions:

1. Does negotiated assessment of metacognitive listening strategies have any significant effect on improving listening comprehension of Iranian EFL learners?

2. Do negotiated assessment and non-negotiated assessment groups significantly differ in enhancing listening comprehension?

\section{Method}

\subsection{Participants}

Participants in the current study were randomly selected from among 90 EFL learners at a private language institute in Tehran, Iran. Their age ranged from 20 to 25 years old. They were all female learners at intermediate level of language proficiency according to evaluation system of the institute. Though the students had been accepted and placed on this proficiency level by the same evaluator and according to the same criteria, a sample of TOEFL test was administered to examine the homogeneity of them. According to the results of the TOEFL, those whose scores fell between one standard deviation below and one standard deviation above the mean were included in the study. Afterwards, these 60 students were randomly divided into two groups- namely experimental and control group. It is worthy of note that both groups were taught by the second researcher who was their regular teacher as well. At the time of the study she was doing her M.A. in TEFL (Teaching English as a Foreign Language). She has been teaching English for 5 years.

\subsection{Instrumentation}

To achieve the objectives of the study, the following instruments were implemented.

\subsubsection{Test of English as a Foreign Language (TOEFL)}

In order to examine the homogeneity of the participants, a sample of TOFEL paper-based version (Philips, 2003) was administered. This test was selected due to the fact that it is a standardized test enjoying acceptable reliability and validity indexes. The reliability index of the TOEFL sample used in this study calculated through Cronbach's alpha was high $(\alpha=.85)$. 


\subsubsection{Listening section of IELTS}

In order to measure listening comprehension of both groups before and after the treatment, two samples of the listening section of IELTS were administered. This test was implemented on the grounds that it is a standardized test which enjoys acceptable reliability and validity indices.

\subsubsection{Interview Checklist}

According to Goh (2010) and Vandergrift (1997), a checklist (Appendix A) was prepared by the researchers. It was given to two applied linguist working and researching on listening comprehension to comment on. Later on, some modifications were made according to the received comments and was piloted with an intermediate class in another institute. Goh pointed out that metacognitive listening strategies fall into four categories: planning, monitoring, evaluation and problem identification. In planning category, the emphasis is placed on helping students with prelistening activities to prepare the students for the purpose and content of listening task at hand. In fact, prediction is of paramount importance here. The second category is monitoring during which the students check the match between their predictions and what they have heard. For the evaluation category, the students discuss the value of the decisions made during task performance with their peers or teachers. Finally, for problem identification category, the students attempted to pin down the barriers and problematic parts of the task hampering their listening comprehension. Additionally, the metacognitive listening strategies were subsumed under the following categories by Vandergrift et al., (2006): problem-solving, planning and evaluation, directed attention, personal knowledge, mental translation. The checklist was divided into 'before-listening' and 'after listening' sections according to Vandergrift's (1997) proposal.

\subsection{Procedures}

At the onset of the study, the sample of TOFEL test was administered and accordingly the participants were assigned to two homogeneous groups in terms of their language proficiency i.e., control and experimental groups. Additionally, both groups took a listening section of IELTS in the following session to determine their listening comprehension before the treatment. Treatment phase of the study spanned eight sessions during which both groups worked on some tasks in Tactics for Listening (Richards, 2011). This book was selected since it was the regular textbook of the institute so it was postulated that the participants would take the tasks seriously; further, it could be assumed that the tasks were at an appropriate level of proficiency for the participants.

In each session, the experimental groups worked on two tasks in their regular textbook while the control group covered three tasks. This difference in the number of the tasks was due to the fact that interactive metacognitive assessment takes a longer time. Therefore, in order to neutralize the intervening effect of time on task, the control group worked on 3 tasks while the experimental group covered only two.

Experimental group's awareness of the metacognitive listening strategies was raised by the teacher two times during each task performance: once during pre-listening stage and the other time during post-listening stage. More specifically, initially, the teacher directed each question of the first section of the checklist to class and called on some of them randomly to answer. The teacher tried to stimulate the students to extend their answers; further, she clarified the students' responses by adopting some strategies such explanation and amplification. Some of the activities in this part encompassed guessing key words, specifying the purpose of the task, and brainstorming useful strategies for unraveling the unknown words. After this initial phase of raising metacognitive awareness, the experimental group listened to the task and did the post-listening activities in the textbook. Later on, the teacher once more drew upon the second part of the checklist and posed the questions to the class and elicited some answers from the students. Like the pre-listening section, the teacher attempted to push learners elaborate on their responses, but if their answers were terse and vague, she herself clarified and complemented them. Some of the activities undertaken in this phase of the study included evaluation of the strategies used for successful listening comprehension and planning for future listening tasks. The control group followed the regular framework of the classroom; that is, they initially read the task instruction, listened to the task, and answer the follow-up activities in the textbook. After eight sessions of treatment, the same post-test, the listening section of IELTS, was administered to both groups.

\section{Results}

The first question was raised in order to examine whether engaging in negotiated assessment of metacognitive listening strategies would make a difference in gains made in listening comprehension of Iranian EFL learners. In order to examine learners' scores on pre- and post-tests, a dependent-samples t-test was run. Descriptive results, as displayed in Table 1, indicated that there is a mean difference between the scores from the pre-test to the post-test so the inferential statistics table was consulted to check whether this discrepancy was significant.

Table 1. Descriptive statistics of the dependent samples t-test on pre-and post tests scores

\begin{tabular}{lllll}
\hline & Mean & N & Std. Deviation & Std. Error Mean \\
\hline Pre-test & 17.17 & 29 & 1.311 & .243 \\
\hline Post-test & 26.07 & 29 & 1.791 & .333 \\
\hline
\end{tabular}

Results of the inferential statistics indicated that there was a significant increase in listening comprehension scores from pre-test $(\mathrm{M}=17.17, \mathrm{SD}=1.31)$ to post-test $(\mathrm{M}=26.07, \mathrm{SD}=1.79), \mathrm{t}(29)=-26.05, \mathrm{p}=.00$ (two-tailed). The mean increase in listening comprehension scores was 9.10 with a $95 \%$ confidence interval ranging from -9.59 to -8.19 . 
Table 2. Inferential statistics for the dependent samples t-test on pre- and post-tests scores

\begin{tabular}{|c|c|c|c|c|c|c|c|c|c|}
\hline & \multicolumn{6}{|c|}{ Paired Differences } & \multirow[b]{3}{*}{$\mathrm{t}$} & \multirow[b]{3}{*}{ df } & \multirow{3}{*}{$\begin{array}{l}\text { Sig. } \\
\text { tailed })\end{array}$} \\
\hline & \multirow[b]{2}{*}{ Mean } & \multirow{2}{*}{$\begin{array}{l}\text { Std. } \\
\text { Deviation }\end{array}$} & \multirow{2}{*}{$\begin{array}{l}\text { Std. } \\
\text { Mean }\end{array}$} & \multirow[t]{2}{*}{ Error } & \multicolumn{2}{|c|}{$\begin{array}{l}\text { 95\% Confidence Interval of } \\
\text { the Difference }\end{array}$} & & & \\
\hline & & & & & Lower & Upper & & & \\
\hline pretest - posttest & -8.89 & 1.83 & .34 & & -9.59 & -8.19 & -26.05 & 28 & .00 \\
\hline
\end{tabular}

The second question intended to compare and contrast the result for the experimental group which received instruction on negotiated assessment of metacognitive listening strategies with the scores for control group which only listened to the same tasks but did not received any instruction on the underlying strategies of listening comprehension. To meet the purpose of this question, an independent samples t-test was conducted on the results of the post-tests for both groups.

Table 3. Descriptive statistics for the independent samples t-test on both groups' post-tests

\begin{tabular}{llllll}
\hline & treatment type & $\mathrm{N}$ & Mean & Std. Deviation & Std. Error Mean \\
\hline listening scores & negotiated assessment & 30 & 26.13 & 1.7 & .32 \\
\hline & no negotiated assessment & 30 & 17.76 & 1.07 & .19 \\
\hline
\end{tabular}

As portrayed in Table 3, there was a mean difference between the post-test scores for both groups in favour of the experimental or negotiated assessment group. Further, as seen in Table 4, the inferential statistics substantiated a significant difference in the scores for non-negotiated group $(M=17.76 ; \mathrm{SD}=1.07)$ and negotiated group $(M=26.13$; $\mathrm{SD}=1.7) ; \mathrm{t}(58)=21.91, \mathrm{P}=.00$ (two-tailed).

Table 4. Inferential statistics for the independent samples t-test on both groups' post-tests

\begin{tabular}{|c|c|c|c|c|c|c|c|c|c|c|}
\hline & & \multicolumn{2}{|c|}{$\begin{array}{l}\text { Levene's } \\
\text { Test for } \\
\text { Equality of } \\
\text { Variances } \\
\end{array}$} & t-test fo & Equ & f Means & & & & \\
\hline & & \multirow[t]{2}{*}{$\mathrm{F}$} & \multirow[t]{2}{*}{ Sig. } & \multirow[t]{2}{*}{$\mathrm{t}$} & \multirow[t]{2}{*}{ df } & \multirow{2}{*}{$\begin{array}{l}\text { Sig. } \\
(2- \\
\text { tailed }) \\
\end{array}$} & \multirow{2}{*}{$\begin{array}{l}\text { Mean } \\
\text { Difference }\end{array}$} & \multirow{2}{*}{$\begin{array}{l}\text { Std. Error } \\
\text { Difference }\end{array}$} & $\begin{array}{l}95 \% \\
\text { Interval } \\
\text { Differenc }\end{array}$ & $\begin{array}{l}\text { Confidence } \\
1 \text { of the } \\
\text { nce }\end{array}$ \\
\hline & & & & & & & & & Lower & Upper \\
\hline \multirow[t]{2}{*}{$\begin{array}{l}\text { listening } \\
\text { scores }\end{array}$} & $\begin{array}{l}\text { Equal } \\
\text { variances } \\
\text { assumed }\end{array}$ & 7.12 & .01 & 21.91 & 58 & .00 & 8.36 & .38 & 7.60 & 9.13 \\
\hline & $\begin{array}{l}\text { Equal } \\
\text { variances } \\
\text { not } \\
\text { assumed }\end{array}$ & & & 21.91 & 58 & .00 & 8.36 & .38 & 7.59 & 9.13 \\
\hline
\end{tabular}

\subsection{Discussion}

The first question was raised in order to examine whether negotiated metacognitive assessment could increase gains in listening comprehension. The results of the study indicated that experimental group's listening comprehension has been enhanced significantly. Further, for the second question, it came to light that the metacognitive awareness group outperformed the control group which did not receive any specific instruction on listening strategies. The results were in line with previous studies such as Vandergrift and Tafaghodtari (2010) and Rahimi and Katal (2013). This can be attributed to that fact that learners might have developed a richer repertoire of listening strategies so that they better managed to regulate and orchestrate listening comprehension processes.

The results were also in consistency with Graham and Macaro (2008); they also found that raising awareness of a body of strategies could assist learners to improve their listening comprehension. Their results were associated with helping the learners to effectively implement a repertoire of cognitive and metacognitive strategies which are appropriate to a specific task at hand. In a similar fashion, Goh and Taib (2006) argued that assisting learners to widen and deepen their understanding and awareness of processes involved in listening put them at a better position to monitor and evaluate their listening comprehension undertaking. Therefore, it can be claimed that engaging in negotiated discussions with the teacher has aided the learners to gain a more in-depth knowledge of the processes underlying listening comprehension and consequently their gains in listening were significantly enhanced. Nonetheless, the control group was not guided and assisted to learn about themselves as listeners, task demands and required strategies for effective task performance. In fact, the learners in control group were not instructed to grow their metacognition. 
Further, the results can be discussed within Vygotskian sociocultural theory as well. This theory is rested upon the premise that all kinds of knowledge are constructed in social contexts by help of more powerful others. That is more skillful partners can help less capable ones to do functions which are beyond their present ability; then, the less capable partners internalize this jointly constructed knowledge and awareness and move towards autonomous task performance (Cross, 2010, Lantolf \& Thorne, 2006). Accordingly, it can be argued that the dialogue between the teacher and the students could mediate to construct further awareness of and knowledge about metacognitive strategies and processes underlying listening comprehension; then, the learners managed to take in the co-built awareness and knowledge and significantly improved. In other words, the dialogue with the teacher could assist the students to outstrip their individual level of abilities. Consequently, they exploited this internalized co-constructed awareness of listening strategies to perform better on the post-test. They could have used the increase in their metacognitive awareness to plan, monitor and evaluate their listening performance.

In sum, the findings were in line with previous studies on literature on metacognitive instruction; for example, Vandergrift, et al. (2006) underscored that instructing metacognitive awareness improves listeners processing and storing ability, aids them to cope with listening problems and deficiencies more efficiently (Goh, 2002), build on the confidence and motivation for listening (Vandergrfit, 2003), and guides them to self-regulate their learning process (Wenden, 1998).

\section{Conclusion}

The findings documented that engaging learners in metacognitive awareness of listening strategies could help them to significantly increase their listening comprehension; further, metacognitive instruction was proved to be more efficient than traditional product-oriented approach in improving listening comprehension. The results suggested that metacognitive instruction can raise learners' awareness of effective strategies and their insights into processes underlying listening comprehension (Cuskun, 2010; Goh, 2010; Vandergrift \& Tafaghodtari, 2010); the findings implied that the metacognitive assessment assisted learners to approach listening tasks more effectively.

The findings of the current study suggest some pedagogical implications. First, language teachers are recommended to attach more weight and prominence to instructing metacognitive awareness of listening strategies. It is obvious that renewing and upgrading teachers' approaches requires the intervention of teacher-educators. The teacher educators can enrich their in-service and pre-service programs by introducing practicing and prospective teachers to researchinformed approaches to teaching listening. Further, as pointed out by Rahimi and Katal (2013) ELT materials and curricula developers have not paid a deserved attention to learning strategies in general and listening strategies in particular, so they are suggested to reconsider and reshape the teaching materials and curricula in light of the findings and designate some space to instructing cognitive and metacognitive listening strategies.

There are some drawbacks to the current study that should be taken into consideration. First, this study was limited to intermediate EFL learners; thus, the generalizability of the findings to other proficiency levels should be investigated by other studies since previous studies (e.g., Cross, 2009; Goh \& Taib, 2010) indicated that metacognitive instruction might not prove efficient for skillful listeners who have reached a ceiling point in listening comprehension. Second, this study was carried out within Iranian context and with adult EFL learners; therefore, other studies can replicate this study in other contexts and with other age groups.

\section{References}

Albeeva, R., \& Stranks, J. (2013). Listening in another language: research and materials. In B. Tomlinson, Applied linguistics and materials development (pp. 199-211). London; New York: Bloomsbury Academic.

Baleghizadeh, S., \& Rahimi, A. H. (2011). The Relationship among listening performance, metacognitive strategy use and motivation from a self-determination theory perspective. Theory and Practice in Language Studies, 1(1), 61-67.

Coskun, A. (2010). The effect of metacognitive strategy training on the listening performance of beginner students. Novitas-ROYAL (Research on Youth and Language), 4(1), 35-50.

Cross, J. (2009). Effects of listening strategy instruction on news videotext comprehension. Language Teaching Research, 13(2), 151-176.

Cross, J. (2010). Metacognitive instruction for helping less-skilled listeners. ELT Journal, 65(4), 408-416.

Fahim, M., \& Fakhri Alamdari, E. (2014). Exploring the effect of the model of metacognitive instruction on the listening performance of EFL learners. International Journal of Research Studies in Language Learning, 3(6).

Flavell, J. H. (1976). Metacognitive aspects of problem solving, In L. B. Resnick (eds..). The nature of intelligence (pp. 231-235). NJ: Hillsdale.

Goh, C. (2000). A cognitive perspective on language learners' listening comprehension problems. System, 28(1), 55-75.

Goh, C. (2002). Exploring listening comprehension tactics and their interaction patterns. System, 30(2), 185-206.

Goh, C., \& Taib, Y. (2006). Metacognitive instruction in listening for young learners. ELT Journal, 60(3), $222-32$.

Goh, C. (2008). Metacognitive instruction for second Language listening development: Theory, practice and research implications. RELC Journal, 39(2), 188-213. 
Goh, C. (2010). Listening as process: Learning activities for self-appraisal and self-regulation. In N. Harwood (eds.), English language teaching materials (pp. 179-206). Cambridge: Cambridge University Press.

Pallant, J. (2010). SPSS survival manual. McGraw Hill, UK.

Rahimi, M., \& Katal, M. (2013). The impact of metacognitive instruction on EFL learners' listening comprehension and oral language proficiency. Journal of Teaching Language Skills, 5(2), 69-90.

Vandergrift, L. (1997). The Cinderella of communication strategies: Reception strategies in interactive listening. The Modern Language Journal, 81(4), 494-505.

Vandergrift, L. (2003). Orchestrating strategy use: Toward a model of the skilled second language listener. Language Learning, 53(3), 463-496.

Vandergrift, L. (2004). Listening to learn or learning to listen? Annual Review of Applied Linguistics, 24, 3-25.

Vandergrift, L. (2005). Relationships among motivation orientations, metacognitive awareness and proficiency in L2 listening. Applied Linguistics, 26(1), 70-89.

Vandergrift, L., Goh, C., Mareschal, C., \& Tafaghodtari, M. H. (2006). The metacognitive awareness listening questionnaire (MALQ): Development and validation. Language Learning, 56(3), 431-462.

Vandergrift, L., \& Tafaghodtari, M. (2010). Teaching L2 learners how to listen does make a difference: An empirical study. Language Learning, 60(2), 470-97.

Wenden, A. (1998). Metacognitive knowledge and language learning. Applied Linguistics, 19(4), 515-537.

\section{Appendix A: Metacognitive awareness checklist}

\section{Pre-listening section}

1. What do you know about this topic?

2. What type of information do you expect to hear?

3. What words do you expect to hear?

4. What difficulties do you expect to encounter?

5. Which strategies can help you to deal with the probable problems?

\section{Post-listening section}

6. Was this recording what you expected?

7. Did you achieve you goal? Why or Why not?

8. Was your listening plan useful?

9. What difficulties did you face?

10. Which strategies help you cope with the problems? 